\title{
The Controlling Process of the Human Capital through the Effective Redistribution of the General Welfare
}

\author{
Zubakov V.M.a \\ Mustafin A.N. ${ }^{b}$ \\ ab Kazan Federal University, Institute of Management, Economics and Finance, Kazan, 420008, Russia
}

\section{Doi:10.5901/mjss.2015.v6n1s3p270}

\begin{abstract}
The controlling process of the human capital during the globalization of the world processes in the innovative development in the economy requires from all the economies an overall approach to tackling the general welfare in their countries. The progressive development of the society in general and innovation processes inside of the economic systems in particular depends on that. We come to a new understanding of the general welfare on that case: the best way of the achieving the general welfare won't be the marginal efficiency of the gain of the individual (personal well-being), but it will be the effective limit of the benefit of the society (general welfare).

Keywords: The controlling process of the human capital, the innovative development, theory of the welfare, Pareto efficiency, distribution of the wealth, the accumulation of the capital, interest of the investments, retirement plans, index of the support, income differentiation, power and standard of the life.
\end{abstract}

\section{Introduction}

British weekly magazine Economist [11] at the peak of the global crisis, said, that the "stragglers rise" was a good achievement, followed by a rise in living standards in the developing world economy. But all the trouble is that the "lift" is accompanied by a "recession" in the world's developed economies (US, Europe, Japan). This is indicated by the fact that the "fall" under the last recession was more pronounced in the world than that - which was accompanied the Great Depression in the 30s of the 20th century. Analysts of OECD countries do not expect a real recovery of the world economy before 2015. Finally, the unemployment rate itself, with the positive changes in the world economy, and does not cause problems for the development of labor market - so this situation is complicated by the fact, that the demographic situation in the employment of the active working population ,in developed countries, has a negative trend. On the other hand, the experts of the Economist continue to state, that the same United States as an example shows that a well-developed economy may "punch" different tests. For example, according to the USA Department of the Commerce statistics, the rate of GDP per capita over the last 150 years has consistently grown: From \$13 thousand dollars. in 1869 - to $\$ 50$ thousand dollars in 2009 (even in the most difficult period of 30-50 years of the 20th century). So, if you take the same indicator (GDP / person.), which will apply to all active working population in the world, the situation won't be so colorful - especially in developed economies. Since 1970, this figure (GDP / slave.) Had lost the positive momentum until the late 20th century, and then it went in different directions: in developing economies, it went up again- plus $4 \%$ to the level of 2010, while in developed markets, it went down again - minus $1 \%$ from 2010. Besides, according to the same Economist, in developed economies around the world observed the growth of debt by non-state institutions. For example, in the USA, the total debt in 2010 was amounted to $\$ 80$ trillion dollars, which include financial business $-\$ 40$ trillion dollars, non-financial business - \$25 trillion dollars, Households - \$15 trillion dollars. In the end, in all these countries, the public expects the biggest cuts in the state budget over the last 40 years. And the main question is that, where they may take the interest of investment savings as a source of general welfare.

\section{Theory}

The modern theory of welfare was originated in the 30s of the 20th century in the sequel and in connection with the theory of general equilibrium. Then the basic theorems of welfare have been rigorously formulated, and the discussion of the limitations associated with them had begun, and the ways to overcome them, and wordings were refined at the same time. The competitive equilibrium in the modern theory and Pareto optimality are regarded as something equivalent. In 
fact, the proof of this equivalence became the fundamental theorems of welfare. The first fundamental theorem states, that if in a competitive equilibrium exists and if all the items were rated on the market, so the equilibrium would be optimal in the meaning of Pareto. It means that, when all the participants of the transaction maximize their utility, the socially efficient allocation of the total product, which maximizes universally, will be received. It is simply to say, that the first law of the welfare encourages to society to go after the market mechanism, which will tell the faithful and the optimal path to the prosperity in society. In other words: this theorem ,formally, expresses the old belief ,that the certain desirable properties belong for the economy of the perfect competition - in another way, in such economy, self-interest inevitably achieves the common good. The new thing in that state is that the establishing of a direct correspondence between the desired state and the position of general equilibrium, although, in principle, it is desirable state can be treated - and as a maximum of personal income, and as a maximum national dividend (R.Kouz) [2]. In addition, the strict wording of the first welfare theorem was proposed by A.Lerner - in 1934 [4], O.Lange - in 1942 [3] and K.Errou - in 1951 [1]. There are various ways to treat perfect competition and neoclassical postulates, but we should recognize one thing: in such deal, as a general welfare, there are no trifles - every person, in a different country, that claims to achieve a civilized status, should be figured and read.

Otherwise, a complete degradation and degeneration waits the country.

\section{Results}

The statistics, which Actuated in the Economist [6], indicate to the following thing: that the average American family income is directly dependent on the level of education of its members: this income rose significantly - from $\$ 70$ thousand dollars. to $\$ 100$ thousand dollars per year, from 1975 to 2009 - in the case if one, of the members of the family, has the bachelor's degree. At the same time, this income wasn't exchanged - it has remained at the level of $\$ 50$ thousand dollars per year - in the case of the absence of degree holders in the family. In this case, the number of holders of bachelor's degree (a measure of professional higher education) for this period of time in the United States increased from $20 \%$ to $30 \%$ of the total mass of young people from 25 to 29 years old. On the other hand, experts of the Economist [10] in their special review noted that in the same America-resident landlords (including their mortgage burden on the household budget) were not able to help their national economy out of the last recession. According to the publication, in the USA from 2001 to 2007 pledges homeowners doubled and reached the amount of $\$ 10.5$ trillion dollars. Not surprisingly, that when from 1950 to 2005 Resident homeowners of America by the end of the first stable year, followed by another recession, output to $1 \%$ of GDP by the volume of its contribution to economic growth, then after the last recession in the world they are in the end of the first Rehabilitation of the year barely scored $0.5 \%$ of GDP - due to their participation in the growth of the economy, and then again "gone" in debt defaults and delinquency. Probably, by this fact the article in Fortune [5] by Browser Sh.Beyr dealt with the US tax code, which is today a differentiated approach to individual income sources, this problem is caused : if you work for hire -you should pay $35 \%$ of the income, if you play on the stock exchange - pay $15 \%$ on dividends and bonuses. The expert told that it wasn't true. According to his words, all the holders of income in the country should be put on an equal footing and they have to pay taxes on the same scale. Especially this fiscal imbalance, according to Sh.Beyr manifested in homeownership: for example, in Canada, unlike the USA, there is no collateral mortgage deduction, but there is not much difference in mortgage products, as well as a little in Canada concessional home ownership.

In Russia Statistics say the following thing: for the first nine months of 2013 there were more than 7.9 million rights to accommodations. This is $17 \%$ more than the same period last year (6.7 million rights), the press of the Federal Service for State Registration service, Cadastre and Cartography (Rosreestr). The Office also recorded a rise in the number of registered rights to residential premises acquired by citizens with a mortgage. Over three quarters of 2013 recorded 897.5 thousand. Rights, while in the first nine months of $2012-870$ thousand rights. Number of registered land rights increased on 5\% - from January to September, there were about 4.8 million. Rights to land, for the first nine months of $2012-4.6$ million rights. In any case, the situation in Russia with housing is not much better than somewhere in the world, of course, the rights are registered - but the price of these rights increases with the increase in prices for the service of the right to housing. We return again to our basic idea: besides their own pension savings, a person in this world there is nothing that can give him the satisfaction of its wealth more reliable than the other criteria for the level and quality of life. These are the stimulus that accompany all conscious and active life of man, even when he has or has not already - no jobs, no housing, no family. Here at this in more detail.

Let's start form the USA. As noted columnist Fortune [8] A.Sloun, he disapproves of the fact that the decrease in personal savings dividends mandatory social insurance funds from the rich taxpayers. And he explains why he thinks so: now paid workers in America covered by insurance from personal pocket in the amount of $25 \%$ of the insurance package 
- $75 \%$ of the generated payroll employer that guaranteed social insurance fund. Underpaid Americans cover their social insurance of personal transfers by only $10 \%$, while the remaining $90 \%$ of its price covered by the employer and the Social Insurance Fund. These personal money, according A.Sloun, accumulate at 35\% per annum in the social insurance fund. As a result, according to his calculations, ordinary Americans, at best while other income, be able to receive at retirement not more than a half over the fact that they themselves put off for life. And the author concludes: Americans are ready to list and more to the social security fund - only on condition that the state will be preserved their "hard-earned dividends."

The magazine Economist [9] averted the whole study to this important question: short, the main "problem" of all pension funds - their content on the part of non-pensioners working in each country. This is so-called "index of support" or «support ratio». Here, experts give the characteristic dynamics in the structure of the pension plan from wage earners in the private sector of the US economy from 1979 to 2009, which shows that the motivation of employees in planning their retirement plans has changed dramatically with the start of a protracted recession of the US economy in the 90 years of the 20th century (Pic. 1):

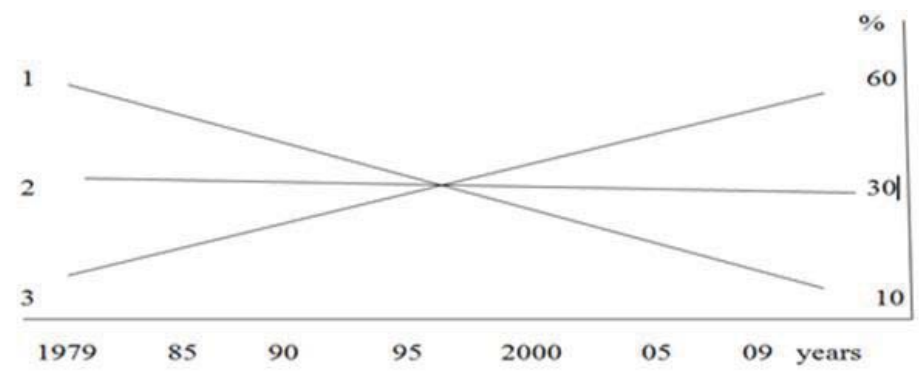

Pic. 1. Structural dynamics of pension plans in the USA economy, where:

1- Pension Plan DB (defined benefit);

2- DC pension plans and DB (together);

3- Pension Plan DC (some contribution).

However, the same experts warn that while good, in general, the dynamics of pension plans when the employee starts to take care of their future pensions, for him there exists the danger of motivation: the individual is prone to underestimate their need at present costs for pensions (DC) and overestimate their potential future earnings on these retirement savings (DB). Meanwhile, as noted in 2010, other experts, pension costs threaten to bring down the economies of many countries, in the next decade, public debt in their social obligations can grow to astronomical proportions. And the hardest of all the developed countries have to - especially so "age" of the economy, such as Japan, the US and the EU old-timers. Analysts believe the agency Standard \& Poor's, for this group of countries is characterized by a relatively high level of the existing social security, while the rapid deterioration of the demographic situation. According to the experts of this agency, the public debt of Russia in their social obligations may rise in 2050 to $570 \%$ of GDP. S\&P analysts believe that countries such as Japan, Russia, Ukraine will have a grand work to reduce its pension costs to an acceptable level [12].

On the other hand, we note that it is the labor market is the main source of capital accumulation and wealth in the country, and hence the incentive for interest from investors. Well-known Russian specialist in the theory of human capital V.V.Andrianova suggested at one time, a simple formula for calculating the value of its growth, in general, and to assess its quality changes, in particular. This formula is following:

$\left.H C=\left[(1+r){ }^{t}-1\right) / r\right] \times A(1)$

where it means:

$\mathrm{HC}$ - human capital (valuation);

$r$ - the discount rate (extracted as root t-th power of the final value, fold increase in the level of average monthly nominal wage of the individual);

$t$ - number of years of active life of the individual;

A - the value of individual life during his active time $t$ (taking into account its consumption rate).

We lead this formula, because it interests us as an indicator of changes of human capital, where we focus our attention on the parameter $\mathbf{t}$ - at the time of the active life of the individual in any society. With regard to the human capital, we are here, we note that, to date, according to experts, only $5 \%$ of the total wealth in Russia formed due to the labor factor, the source of $20 \%$ of the total accumulation of capital and the factor of $75 \%$ of the wealth generated in the 
Russian economy by a factor of natural resources or natural resource rents, as economists say. At the end of the 20th century, the World Bank (WB) has proposed a new concept of measuring national wealth (income and capital) of the country, which includes: human, natural and reproducible capital. Unlike traditional indicators of the wealth, a new concept of capital accumulation in the country provides the opportunity to judge both on the extent of accumulation of wealth, as a whole, on the extent of the accumulation of all the elements of accumulation against the general population (Table 1).

Table 1: The structure of the accumulation of wealth at the beginning of the 21st century in the world - by country (region) and on the main factors of this accumulation

\begin{tabular}{|l|c|c|c|c|}
\hline \multirow{2}{*}{ Region } & \multirow{2}{*}{ Altogether } & \multicolumn{3}{|c|}{ В том числе, капитал: } \\
\cline { 3 - 5 } & & Human & Natural & Reproducible \\
\hline (in \$ thous. doll. / per capita) & 400 & 200 & 160 & 40 \\
\hline Russia & 326 & 249 & 15 & 62 \\
\hline USA and Canada & 302 & 205 & 6 & 91 \\
\hline Japan, Australia, New Zealand & 237 & 177 & 5 & 55 \\
\hline Europe & 150 & 65 & 58 & 27 \\
\hline Near East & & &
\end{tabular}

Source: The Complete World development report online [13]

\section{Conclusions}

The Economist Edition [7] in the material, devoted to the International Forum in Davos, has allocated two problems in the next decade - "failures" of global risk management and the increase of the wealth inequality in all countries of the world. The expert explained that during the previous two decades dominated by the so-called "Davos consensus" that takes the view: the problem of income inequality is not more important than the task of raising the standard of living of those who are at the bottom of the social ladder. How do we know that, the problem of income differentiation in society and the related differences in levels of opportunities to members of the public acquisition of personal wealth could only be solved in the complex and in conjunction with all available sources of savings in the country and the general mechanisms of redistribution of accumulated welfare.

\section{References}

Arrow K. An Extension of the Basic Theorems of Classical Welfare Economics. Berkley Symposium on Mathematical Statistics and Probability. Berkley, 1951

Coase R. The Problem of Social Costs // Journal of Law and Economics. 1960. Vol. 3. № 1

Lange O. The Foundation of Welfare Economics / Econometrica. 1942. Vol. 10

Lerner A. Economic Theory and Socialist Economy // Review of Economic Studies. 1934. №2

Beir S. On taxes // Fortune, April 2, 2012, p. 34

Askhatova, L.I., Bulnina, I.S. Quality-of-life (QOL) improvement as a strategic resource of sustainable social and economic development of a region. Life Science Journal, Volume 11, Issue 6 SPEC. ISSUE, 2014, Pages 354-35.

Brain conquer the world? // Economist, January 22-28, 2011, c. 10

Davos // Economist, January 22-28, 2011, p. 11

Slown A. On insuring // Fortune, April 2, 2012, p. 32

Safiullin, N.Z., Gafurov, I.R.,Safiullin, L.N., Odintsova, J.L. Education system of the world: Modern trends. Mediterranean Journal of Social Sciences, 5 (18 SPEC. ISSUE), pp. 91-94.

Special report on pensions // Economist, April 9-15, 2011, p. 9

Yafizova D.A., Shigabutdinov A.F. Revisiting the issue of the long-run competitiveness of the National Petrochemical Complex/ Life Science Journal 2014;11(8s), pp. 168-171.

Special report on property // Economist, March 5-11, 2011, p. 7

World report // Economist, Oktober 9-15, 2010, p. 3-4

http://www.standardandpoors.com/2010/

Bulnina, I.S., Askhatova, L.I. Propositions and suggestions addressed to implement the provisions of the Russian federal law No 217. Mediterranean Journal of Social Sciences, Volume 5, Issue 18 SPEC. ISSUE, 2014, Pages 129-132. 